\title{
INTERAKSI EDUKATIF DALAM PROSES BELAJAR MENGAJAR
}

\begin{abstract}
Abtraksi
Murid adalah objek dari dunia pendidikan yang akan diarahkan pada kemandiri diri dalam segala hal sehingga menjadi pribadi yang akan maksimal dalam mengaktualisasikan dirinya dalam masyakat .Guru merupakan subjek yang akan mengubah murid dengan dinamis.Banyaknya siswa yang takut dengan guru karena terkadang guru menunjukkan sikap-sikap yang tidak bersahabat bahkan menjadi momok yang menakuti siswa merupakan masalah besar dalam dunia pendidikan.Hubungan guru dengan siswa memiliki peranan yang sangat penting yang harus terus dibangun karena hubungan yang baik antara siswa dengan guru akan memicu semangat siswa dalam belajar.Dalam setiap hubungan yang berkualitas yang dibangun antara siswa dengan guru justru didalam kesempatan tersebut nilai-nilai kebenaran akan sangat efektif ditanamkan sehingga terjadi pembelajaran yang dinamis.
\end{abstract}

Menjadi seorang guru bukanlah hal yang mudah.Seorang guru sejati tidak hanya sekedar mentransfer ilmu yang dimiliki kepada para siswa melainkan juga mengajarkan nilai-nilai kehidupan dan perilaku hidup yang baik dan bermartabat.Sehingga guru harus menjadi panutan dalam kehidupan sehari-hari,baik dilingkungan sekolah maupun dilingkungan masyarakat.Peran guru dalam aktivitas pembelajaran sangat kompleks. Guru tidak sekedar menyampaikan ilmu pengetahuan, tetapi juga dituntut untuk memainkan berbagai peran yang bertujuan untuk mengembangkan potensi peserta didik secara optimal.

Guru terkadang lebih banyak menjaga hubungannya dengan siswa agar wibawanya sebagai seorang guru dihargai.Bagi sebagian guru, berteman dengan siswa merupakan hal yang tabu karena dianggap dapat menurunkan harkat dan martabat guru yang mulia dan 
agung, maka hubungan yang erat dengan siswa banyak yang dihindari. Entah disadari atau tidak, seringkali guru membangun tembok pemisah yang membentengi dirinya dari kedekatan dengan siswa. Guru lupa untuk menjalin hubungan yang humanis dengan siswa.Guru bersikap bahwa siswa itu tidak perlu dekat dengan guru karena nanti kalau terlalu dekat hubungannya dengan siswa maka guru tersebut tidak akan dihormati.

Dalam proses belajar mengajar,guru banyak menampilkan sikap-sikap garang,pesimis dan bahkan cenderung pemarah.Penampilan yang ditunjukkan juga dalam bahasa-bahasa tubuhnya adalah sikap penolakan akan keberadaan keaktifan siswa.Guru mendudukkan dirinya pada posisi yang tinggi, posisi yang berhak memerintah dan mengatur tanpa ada kata bantahan. Siswa diposisikan sebagai pihak yang lemah, yang harus menerima segala titah dan menuruti segala perintah.Persoalan hubungan antara guru dan siswa yang kurang baik akan membuat suasana belajar menjadi kurang menarik dan akan membuat tidak terjadinya interaksi belajar yang positif sehingga per-transferan pengetahuan itu tidak sesuai dengan yang diharapkan. Ruangan kelas sebagai tempat belajar menjadi sangat tidak menarik. Guru seringkali berlaku seperti momok yang sangat menakutkan yang mengada-ada tanpa dasar yang logis bahkan meneror fisik dan psikis. Menebarkan suasana ketakutan sampai ke relung hati siswa. Bagi siswa, ruang kelas adalah tempat penyiksaan, pelajaran dirasa sebagai hukuman, detak jam berlalu begitu lambat, sebaliknya bunyi bel adalah sesuatu yang sangat dinanti sebagai alat pembebas.Padahal ruangan kelas merupakan salah satu rumah kedua bagi guru dan siswa yang sedang melakukan proses belajar mengajar di lembaga pendidikan formal baik SD, SMP, ataupun SMA. Tapi sekarang banyak kita mendengar bahwa banyak guru dan siswa yang tidak betah berlama lama di kelas karena mereka beranggapan suasananya tidak kondusif dan kaku. Hubungan yang tidak baik antara guru dengan siswa 
akan mengganggu proses pembelajaran, yang akan membentuk perilaku agresif atau pasif yang dapat menimbulkan kesulitan dalam bekerja sama dengan guru dan bahkan sesama siswa. Sekolah atau situasi proses belajar mengajar menjadi banyak bermasalah.Padahal suasana belajar yang bagus itu adalah dimana guru dan murid sama-sama tertarik dalam pembelajaran.

Manusia sebagai makhluk sosial selalu membutuhkan kehadiran manusia lain dalam kehidupannya. Keberadaan manusia selain diri kita menyebabkan proses hubungan timbal balik terjadi secara alamiah. Proses jalinan hubungan antar individu maupun kelompok terjadi dalam rangkaian upaya memenuhi kebutuhan. Motif saling membutuhkan yang berbeda-beda membuat manusia saling melayani kebutuhan manusia lain.Kecenderungan manusia untuk berhubungan melahirkan komunikasi dua arah melalui bahasa, yang mengandung tindakan dan perbuatan. Oleh karena ada aksi dan reaksi tersebut maka interaksipun terjadi.

Proses belajar mengajar merupakan proses kegiatan interaksi antara dua unsur manusia, yakni siswa sebagai pihak yang belajar dan guru sebagai pihak yang mengajar, dengan siswa sebagai subjek pokoknya. Fungsi siswa dalam interaksi belajar-mengajar adalah sebagai subjek dan objek pendidikan ${ }^{1}$ Di dalam proses belajar mengajar, guru memegang peranan yang sangat penting.Proses pembelajaran akan efektif, jika komunikasi dan interaksi antara guru dengan siswa terjadi secara intensif. Guru mempunyai peran ganda dan sangat strategis dalam kaitannya dengan kebutuhan siswa. Peran dimaksudkan adalah bagaimana guru mampu membangun hubungan yang positif dengan siswa sehingga nara

\footnotetext{
${ }^{1}$ Tholib Kasan,Op.cit.,hal.38.
} 
didik memiliki suatu semangat dan motivasi yang baik untuk mengikuti pembelajaran .Hubungan yang baik antara guru dan murid akan dapat mendorong murid untuk lebih aktif dan lebih bergairah dalam belajar karena kegiatan belajar dan mengajar yang berdaya guna dimaksudkan untuk mencapai tujuan pengajaran atau pembelajaran. Dalam proses belajar mengajar, hubungan yang harmonis antara guru dan siswa sangat diperlukan. Keberhasilan pembelajaran tergantung pada kedua belah pihak yaitu guru sebagai pendidik dan siswa sebagai anak didik. Hubungan yang efektif antara guru dan siswa akan mempermudah siswa menerima dan mempelajari pelajaran tersebut. Bagaimanapun sulitnya materi pelajaran, jika guru dan siswa memilki hubungan yang baik maka siswa akan mampu mempelajarinya dengan baik. Siswa akan merasa bahwa belajar bukanlah suatu beban apabila hubungan dengan guru berlangsung dengan baik.Belajar bagi siswa akan senantiasa menjadi sangat menarik sehingga memperbesar minat belajar siswa.

Kata hubungan dalam bahasa Inggris menggunankan kata "relationship" yang memiliki arti adalah kesinambungan interaksi antara dua orang atau lebih yang memudahkan proses pengenalan satu akan yang lain.

Hubungan terjadi dalam setiap proses kehidupan manusia. Hubungan dapat dibedakan menjadi hubungan dengan teman sebaya, orangtua, keluarga, dan lingkungan sosial.Secara garis besar, hubungan terbagi menjadi hubungan positif dan negatif.Hubungan positif terjadi apabila kedua pihak yang berinteraksi merasa saling diuntungkan satu sama lain dan ditandai dengan adanya timbal balik yang serasi. Sedangkan, hubungan yang negatif terjadi apabila suatu pihak merasa sangat diuntungkan dan pihak yang lain merasa dirugikan.Dalam hal ini, tidak ada keselarasan timbal balik antara pihak yang berinteraksi.Lebih lanjut, hubungan dapat menentukan tingkat kedekatan dan kenyamanan antara pihak yang 
berinteraksi.Semakin dekat pihak-pihak tersebut, hubungan tersebut akan dibawa kepada tingkatan yang lebih tinggi.

Yesus sebagai seorang guru Agung merupakan pribadi yang mengerti akan makna dari hubungan atau relasi dengan murid-murid-Nya,sehingga kalau kita membaca Firman Tuhan terlebih dalam seluruh Injil maka disitu banyak ditampilkan tentang bagaimana Yesus bersama dengan muridnya memilki hubungan yang kuat sehingga kemana saja Yesus pergi murid-murid pasti ada disana.Hubungan Yesus yang baik dengan para murid-murid-Nya membuat para murid-murid memiliki suatu semangat dalam mempelajari segala konsepkonsep Kerajaan Allah.Pengajaran agama dalam Perjanjian Baru mengalami revolusi besar dengan munculnnya pengajaran Kristus yang sangat berbeda dalam hubungannya dengan murid-murid yang Dia ajar.

Dalam cara mengajar Yesus Kristus maka dapat dilihat bagaimana Yesus Kristus selalu menghabiskan waktu bersama-sama dengan murid-murinya dalam bayak hal. Metode pengajaran Yesus adalah keterlibatan pribadi. Dia memanggil murid-murid-Nya untuk bersama-Nya. Murid-murid Yesus ada bersama-Nya pada perjalanan, doa, ibadah, makan, berlayar, penyembuhan, mengusir setan dan memancing pergi kekota, rumah-rumah ibadat, rumah saudara, pesta pernikahan dan pemakaman. Mereka berbagi kehidupan satu sama lain. Dia membawa murid-murid-Nya dekat dengan-Nya dalam persahabatan .Namun dalam seluruh hubungan kebersamaan itu Yesus banyak melatih para murid-murid.Dia mengatakan kepada murid-murid yang Dia ajar, bahwa mereka tidak hamba-Nya tapi temanteman-Nya seperti yang tertulis dalam Yohanes 15:15 "Aku tidak menyebut kamu lagi hamba, sebab hamba tidak tahu, apa yang diperbuat oleh tuannya, tetapi Aku menyebut 
kamu sahabat, karena Aku telah memberitahukan kepada kamu segala sesuatu yang telah Kudengar dari Bapa-Ku”.

Dalam hubungan bersama dengan murid-murid-Nya Yesus menunjukkan bagaimana Ia memberitakan Injil,mengajarkan nilai-nilai kebenaran Firman dengan cara-cara yang sederhana. Pelayanan pendidikan atau mengajar adalah merupakan pelaksanaan Amanat Agung Tuhan Yesus $^{2}$.Dalam hubungan dengan murid-murid yang selalu bersama-sama dengan Dia ,Yesus mengundang mereka untuk berpartisipasi dalam ajaran-Nya, bukan untuk mempelajarinya tapi juga mempraktekkan. Dalam kebersamaanya dengan muridmurid Ia banyak mempertontankan muijizat dengan menolong orang yang kesulitan dalam pesta pernikahan di Kana (Yohannes 2:1-11), mempedulikan perempuan Samaria yang berdosa (Yohanes 4:1-42), menyembuhkan anak pegawai istana (Yohanes 4:46-54), memberi makan lima ribu orang (Yohanes 6:1-15), menyembuhkan orang-orang sakit (Yohanes 5:1-18; Yoh 9), dan membangkitkan Lazarus (Yohanes 11:1-44) dan lain sebagainya. Yesus dalam kebersamaannya dengan murid-murid juga selalu bersedia menerima undangan makan di rumah-rumah orang berdosa yang terasing dari masyarakat sebagai kesempatan untuk mengajarkan kebenaran rohani kepada orang-orang yang hadir pada undangan itu . Yesus terus menerus bersama dengan murid-murid mengajarkan Injil dan mengajar di mana orang-orang berada, baik di rumah, di tempat terbuka, di bukit, di pantai, di perahu, di pelataran Bait Suci, di sinagog-sinagog (rumah ibadah Yahudi) ${ }^{3}$. Tujuannya supaya orang-orang tersebut di mana pun mereka berada dapat percaya dan menerima Dia sebagai Mesias, Anak Allah. Selain itu, Ia juga terbuka dalam menerima

\footnotetext{
${ }^{2}$ Khoe Yao Tung,Op.cit.h.269

${ }^{3}$ J.M,Price, Yesus Guru Agung,(Bandung:Lembaga Literatur Baptis,2011), hal.124
} 
semua orang yang dapat kepada-Nya. Ia medemostrasikan yang Dia perkatakan dengan tindakan-tindakan nyata kepada murid-murid dalam hubungan kebersamaan-Nya dengan mereka.Dalam hubungan kebersamaan itu Dia mengajak murid-murid untuk mengamati Dia dan belajar dengan mengajukan pertanyaan dan kemudian mengambil kesimpulan dari seluruh situasi yang ada,seperti yang tertulis dalam Yohanes 9:1 "Waktu Yesus sedang lewat, Ia melihat seorang yang buta sejak lahirnya.2 Murid-murid-Nya bertanya kepadaNya: "Rabi, siapakah yang berbuat dosa, orang ini sendiri atau orang tuanya, sehingga ia dilahirkan buta?"3 Jawab Yesus: "Bukan dia dan bukan juga orang tuanya, tetapi karena pekerjaan-pekerjaan Allah harus dinyatakan di dalam dia.4 Kita harus mengerjakan pekerjaan Dia yang mengutus Aku, selama masih siang; akan datang malam, di mana tidak ada seorang pun yang dapat bekerja.5 Selama Aku di dalam dunia, Akulah terang dunia.".Dari semua yang sudah dipertontonkan Yesus kepada murid-murid Yesus memberikan kesempatan kepada murid-murid untuk menemukan kebenaran-kebenaran bagi diri mereka sendiri. Dengan jawaban-jawaban yang Yesus berikan Dia membimbing, mengarahkan, sehingga murid-murid semakin mengerti dengan baik apa yang diingikan oleh Bapa disorga bagi mereka. Yesus dalam seluruh hubungan kebersamaannya dengan muridmurid berusaha membimbing murid-murid agar dapat menemukan berbagai potensi yang dimilikinya sehingga murid-murid mampu mencapai dan melaksanakan tugas-tugas yang akan diembankan pada murid-murid kelak.Murid-murid yang Dia latih dan bina itu adalah pribadi dan kelompok yang belum berkembang, impulsif, berdosa, kacau pikiran, bodoh, berprasangka dan tidak stabil.Seperti Petrus dan saudaranya Andreas ,mereka yang adalah latar belakang nelayan di Danau Galilea (Mat. 4:18, Mrk. 1:16). Ia berbicara dengan aksen orang Galilea, dan kebiasaan-kebiasaannya yang aneh membuat orang mengenalinya 
sebagai seorang penduduk asli daerah perbatasan Galilea (Mrk. 14:70). Dia seorang yang suka berbicara terus terang dan tidak terlalu menyukai basa basi dalam perkataannya. Petrus sering berbicara sebelum ia memikirkannya. Petrus adalah pribadi yang memiliki rasa ingin tahu besar terhadap sesuatu, sekaligus juga terkadang ingin lebih hebat dari pada rata-rata para murid Yesus lainnya. Karena sifatnya itu, Petrus menjadi pribadi yang cenderung lebih menonjol sekaligus pribadi yang terkesan suka usil ingin tau urusan orang lain (Yohanes 21:20-23). Hubungan kebersamaan yang dibuat oleh Yesus ini berlangsung di sekitar kehidupan murid-murid dan memberikan nilai-nilai edukatif kepada murid-murid, yakni hubungan yang dengan sadar dilakukan Yesus untuk meletakkan tujuan mengubah tingkah laku dan perbuatan murid-murid.Hubungan yang dibagun oleh Tuhan Yesus ini menggambarkan hubungan aktif dua arah dengan sejumlah pengalam langsung sebagai mediumnya, sehingga hubungan itu merupakan hubungan yang bermakna dan kreatif.Secara sadar dan tersistematis Tuhan Yesus mempunyai tujuan untuk mendidik dan untuk mengantarkan murid-murid pada arah kedewasaan iman dalam hubungan kebersamaan yang Yesus ciptakan dengan sengaja. Hal yang dilakukan oleh Tuhan Yesus ini dalam dunia pendidikan dinamakan dengan istilah “interaksi edukatif”. Interaksi edukatif adalah proses interaksi yang disengaja, sadar tujuan, yakni untuk mengantarkan anak didik ketingkat kedewasaannya ${ }^{4}$.

Dalam kebersamaan Yesus Kristus dengan para murid-murid maka Dia banyak mengajarkan kebenaran-kebenaran dan prinsip tujuan mereka bersama dengan Yesus Kristus.Metode yang digunakan oleh Yesus Kristus adalah metode yang sangat indah karena disaat-saat mereka bersama dalam menghadapi berbagai ragam persoalan,justru didalam situasi-situasi

\footnotetext{
${ }^{4}$ Sadirman A.M, Interaksi dan Motivasi Belajar Mengajar, (Jakarta:PT. RajaGrafindo Persada, 2010), hal 18
} 
tersebutlah Yesus Kristus banyak mengajar para murid-murid. Dengan metode seperti itu mengajar para murid-murid sebagaimana terlihat ketika Ia menolong orang yang kesulitan dalam pesta pernikahan di Kana (Yohannes 2:1-11), mempedulikan perempuan Samaria yang berdosa (Yohanes 4:1-42), menyembuhkan anak pegawai istana (Yohanes 4:46-54), memberi makan lima ribu orang (Yohanes 6:1-15), menyembuhkan orang-orang sakit (Yohanes 5:1-18; Yoh 9), dan membangkitkan Lazarus (Yohanes 11:1-44). Yesus juga selalu bersedia menerima undangan makan di rumah-rumah orang berdosa yang terasing dari masyarakat sebagai kesempatan untuk mengajarkan kebenaran rohani kepada muridmurid-Nya. Yesus Kristus terus menerus mengajarkan Injil dan mengajar di mana orangorang berada, baik di rumah, di tempat terbuka, di bukit, di pantai, di perahu, di pelataran Bait Suci, di sinagog-sinagog (rumah ibadah Yahudi) ${ }^{5}$. Tujuannya supaya murid-murid tersebut dapat percaya dan menerima Dia sebagai Mesias, Anak Allah.

Dalam sistim mengajar yang dilakukan oleh guru-guru Yahudi ,para guru Yahudi mengambil suatu tempat yang bisa didengar oleh para muridnya dan muridnya menerima pengetahuan dan metode dari dia.Tetapi pola yang dipakai oleh Yesus Krsitus sangat berbeda,murid-murid yang ingin belajar dari Yesus tidak hanya untuk belajar sejumlah pokok doktrin atau ketrampilan penafsiran-penafsiran dari seorang guru tetapi mereka dipanggil untuk selalu bersama dengan Yesus, dan mendengarkan perkataan-perkataanNya dan mengikuti teladan-Nya supaya mereka boleh menjadi rekan sekerja dengan Dia dalam karya-Nya bagi kerajaan surga. Jadi, Yesus Kristus mengajar selalu disertai dengan contoh, teladan, dan praktik, seperti bagaimana memberitakan Injil ( Yohanes

\footnotetext{
${ }^{5}$ J.M.Price,Op.cit,h.124
} 
4), melayani, mengajar, dan menggembalakan domba-domba-Nya ( Yohanes 10). Tuhan mengajar dan melatih murid-muridNya melalui pelbagai cara.Ketika mereka kekurangan makanan ( Yohanes 6:1-15),reaksi murid-murid adalah 5 roti dan 2 ikan yang tidak mencukupi untuk mengenyangkan orang ramai.Roti seharga dua ratus dinar tidak cukup untuk mengenyangkan orang ramai .Keadaan tersebut memperlihatkan bahwa murid-murid Yesus Kristus kekurangan iman.Cara Yesus Kristus mengatasinya dan diperlihatkan pada murid-murid yang sedang diajar-Nya adalah mengucap berkat ke atas roti itu dan mengenyangkan orang banyak bahkan potongan-potongan roti sisa melebihi 12 bakul.Hal yang diajarkan Yesus Kristus adalah dengan adanya iman dan penyertaan Allah Bapa maka murid-murid takkan kekurangan selama-lamanya.Melalui angin ribut ( Yohanes 6:16-21) reaksi murid-murid Tuhan pada waktu itu sudah sangat ketakutan namun Yesus Kristus meredakan angin ribut tersebut.Keadaan tersebut memperlihatkan bahawa murid-murid kurang percaya dan kembali Yesus Kristus mengajar murid-murid agar semakin yakin dan percaya pada-Nya. Tujuan Yesus Kristus dalam mengajar murid-murid ialah membentuk cita-cita luhur dalam diri para murid-Nya, membentuk keyakinan yang teguh, memiliki hubungan dengan Allah dan sesamanya. Para murid didorongNya agar kreatif menghadapi masalah hidup sehari-hari dan memiliki watak yang bagus dalam menjalankan tugas pelayanan. Pengajaran Yesus Kristus berhasil dalam rangka mengangkat derajat para murid, mengubah kehidupan mereka agar percaya kepada-Nya. Yesus Kristus senantiasa menyesuaikan pengajaran-Nya dengan keadaan dan kebutuhan para murid. Dia menyentuh suara hati mereka serta merangsang mereka untuk aktif berbuat. Bahan pengajaran Yesus Kristus diambil dari Perjanjian Lama lalu diintegrasikan dengan peristiwa alam dan peristiwa yang hangat yang sedang terjadi. Dia menggunakan pepatah, ilustrasi, 
perumpamaan dalam memulai atau dalam menjalankan pengajaran pada murid-murid .Susunan pengajaran- pengajaran Yesus amat menarik, diawali pendahuluan, isi dan kesimpulan.Metode pengajaran Yesus yang dibangun dalam kebersamaan dengan muridmurid amat variatif karena mencakup cerita, ceramah dan tanya jawab yang terjadi diantara mereka.Beberapa metode yang dipakai Yesus Kristus dalam mengajar ditengah-tengah kebersamaan-Nya dengan para murid-murid :

\section{Tuhan Yesus menggunakan perumpamaan (paroimia) (Yohanes 10:1-21,}

\section{$15: 1-15)$}

Dalam saat Yesus Kristus bersama-sama dengan para murid-murid Ia selalu menyampaikan pengajaran-Nya pada murid-murid Yesus Kristus dengan seringkali menggunakan perumpamaan .Didalam seluruh kitab Injil, Yesus Kristus menggunakan perumpamaan sebanyak 40 kali. Kata perumpamaan dalam bahasa Yunani adalah paroimia .Kata ini dapat berarti amsal, perumpamaan, alegori, kiasan, fabel, perbandingan sederhana, bahasa simbolis. Ini biasanya mengandung perkataan atau gambaran yang bersifat figuratif atau kebenaran yang masih belum jelas yang perlu ditafsirkan lebih lanjut dengan memakai gaya hidup yang sesuai dengan situasi para pendengarnya.

Yesus Kristus terkadang menjadikan perumpamaan sebagai titik awal untuk masuk ke dalam pesan dan pengajaran pada murid-murid. Hal ini juga memperlihatkan Yesus Kristus sebagai seorang guru yang mahir telah menggunakan hal yang umum (paroimia) dari dunia alam sekitar-Nya untuk mengajarkan makna etis maupun teologis kepada para murid-murid -Nya.

\section{Yesus Kristus menggunakan dialog-dialog ( Yoh $2: 13-22 ; 3 ; 4 ; 8: 37-59 ; 14: 1-14$ )}


Dalam Injil Yohanes, Yesus Kristus terutama menggunakan dialog-dialog dalam pemberitaan dan pengajaran tentang kebenaran rohani.Seperti contoh dialog-Nya dengan perempuan Samaria, dengan Nikodemus, dengan orang-orang Yahudi, dengan orang banyak, dengan para pemuka Yahudi, dan dengan murid-murid-Nya.Penggunaan dialog dalam mengajarkan sesuatu bagi Yesus Kristus begitu penting dalam memasukkan pengertian yang Yesus Kristus inginkan untuk di pahami oleh para murid-muridNya.Karena melalui dialog, Yesus Kristus dapat menggunakan konsep-konsep umum dan riil, seperti air, sebagai cara alami untuk membangkitkan ketertarikan, dan secara pelan-pelan memimpin para murid-murid untuk percaya kepada Yesus sebagai Mesias (Yohanes 4:26) dan mendapatkan hidup yang kekal. Melalui dialog, Yesus Kristus dapat berinteraksi secara langsung dan mengikutsertakan murid-murid dalam .Melalui metode ini Yesus Kristus dapat memperkenalkan diri-Nya dan karya-Nya sebagai Mesias, Anak Allah dan dapat memimpin para murid-murid mendengar melalui satu proses penemuan dan pengenalan pribadi mereka terhadap Yesus Kristus dan mendapatkan hidup yang kekal. Melalui dialog, Yesus Kristus dapat memakai makna ganda untuk menyatakan realitarealita rohani dalam bahasa manusia, sesuai dengan situasi dan nilai yang sangat dipegang oleh para murid-murid. Contoh: air, haus, makanan. Melalui dialog, Yesus Kristus bukan hanya dapat mengintroduksi tema-tema dialog tetapi juga terbuka bagi pertanyaan-pertanyaan yang mengganjal dari para murid-murid-Nya. Karena melalui dialog, Yesus Kristus sebagai guru yang baik dapat mengetahui sejauh mana pengertian para murid-murid-Nya dan akhirnya dapat menggunakan strategi dan taktik yang sesuai dalam menjelaskan kebenaran rohani, identitas-Nya, dan karya-Nya sebagai Mesias atau Anak Allah. 


\section{Yesus Kristus secara khusus banyak menggunakan simbol atau metafor dalam mengajarkan kebenaran rohani pada murid-murid (Yohanes 15:1-8,dll)}

Simbol merupakan satu mata rantai penghubung di antara dua lingkungan yang berbeda, yaitu antara apa yang kita ketahui dan apa yang kita tidak ketahui, antara yang abstrak dan yang konkret, antara yang terbatas dan tidak terbatas. Simbol dapat memperjelas makna .Penggunaan simbol-simbol oleh Tuhan Yesus bertujuan untuk menyampaikan hal-hal abstrak berkaitan dengan nilai-nilai rohani dalam bahasa-bahasa manusia yang simbolis supaya lebih mudah dimengerti oleh para pendengar atau pembacanya. Tujuannya supaya mereka dapat percaya bahwa Tuhan Yesus adalah Mesias. Fungsi simbol atau metafor adalah untuk menimbulkan bayangan yang mudah dimengerti sehingga mereka dapat dipimpin masuk ke maksud atau tujuan dari Tuhan Yesus melalui realita baru yang diciptakan simbol-simbol tersebut

\section{Tuhan Yesus menggunakan wacana (Yoh 5:19-47; 6:25-66; 7:14-44; 8:12-59; 10;}

\section{2:20-36; 13-16).}

Dalam Injil, Yesus Kristus juga banyak sekali menggunakan wacana dalam mendekati para murid-murid-Nya. Tujuannya untuk membawa mereka yang diajarnya percaya kepada Bapa dan kepada diri-Nya sebagai Mesias, Anak Allah yang diutus oleh Bapa. Isi wacana Yesus Kristus baik berkaitan dengan penyataan diri-Nya tentang Bapa, identitas dan karya misi-Nya menyangkut keselamatan dan hidup kekal bagi orang-orang yang percaya, kedatangan Roh Kudus, dan misi Yesus Kristus melalui murid-murid yang akan datang.

5. Yesus Kristus menggunakan pertanyaan-pertanyaan atau tanya jawab, paradoks, tindakan-tindakan figuratif, argumentasi-argumentasi , gaya-gaya bahasa, 
permainan kata, supaya para muri-murid-Nya dapat mengerti apa yang disampaikan-Nya dan mempercayai Dia sebagai Mesias, Anak (Yo 11:12-16)

Manusia adalah mahluk berfikir yang dengan itu menjadikan dirinya memilki keinginan untuk belajar. Dengan berfikir, dengan bertanya, manusia menjelajahi pengembaraannya, mulai dari dirinya sendiri kemudian lingkungannya bahkan kemudian sampai pada hal-hal lain yang menyangkut asal mula atau mungkin akhir dari semua yang dilihatnya. Kesemuanya itu telah menempatkan manusia sebagai mahluk yang berbeda dengan hewan. Yesus Kristus dalam dalam pelayanan mengajar selalu memberikan kesempatan bagi para murid-murid-Nya yang diajarnya memberikan ruang tanya jawab ( Yohanes 6:67-71). Tuhan Yesus sangat membangun dialog-dialog yang hidup dan menggugah rasa ingin tahu para murid-murid-Nya.Tanya jawab adalah jantung dari mengajar yang baik. Memilih berbagai tipe pertanyaan yang tepat untuk ditanyakan pada siswa adalah hal yang penting untuk mengasah pemikiran yang memancing berbagai jawaban dan melibatkan siswa dalam diskusi yang produktif. Yesus Kristus mengajar dengan memakai metode tanya jawab yang berkaitan dengan penyelidikan dan pertanyaan-pertanyaan yang menantang yang dibutuhkan dalam kecakapan pemikiran kognitif yang lebih tinggi seperti misalnya analisis, perpaduan dan pengujian. Dengan mengajukan pertanyaan-pertanyaan menantang, Yesus Kristus mengajak murd-murid orang yang diajarnya untuk menggali berbagai ide dan menerapkan pengetahuan baru ke dalam berbagai situasi lain.Menggunakan berbagai tipe tanya jawab yang berbeda membiarkan siswa berpikir dalam berbagai cara yang berbeda dan unik.

\section{Tuhan Yesus memakai pengalaman murid-murid-Nya untuk mengajar mereka.}


Sebagai dasar untuk model dalam membagun cara pengajaran yang yang baru dan sederhana

, Yesus Kristus menyebut hal-hal yang lazim dialami oleh para murid-murid dengan menghubungkan peristiwa-peristiwa dari hidup sehari- hari yang dialami dan dilihat para murid-murid sehungga lebih mudah dipahami (Yohanes 10:1-19,15:1-7). Hal-hal seperti itu dapat dimengerti, dan juga akan mengingatkan mereka kepada ajaran itu tiap kali mereka melakukannya lagi.

\section{Tuhan Yesus terkadang menunjukkan obyek-obyek yang konkrit untuk dilihat para murid-murid.}

Ia memakai angin (Yohanes 3:8), roti (Yohanes 6:35), pintu (Yohanes 10:9) yang kelihatan di mana- mana sehingga akan mengingatkan pendengar-Nya akan ajaran-Nya tiap kali mereka melihat barang itu kelak .

\section{Tuhan Yesus memakai cerita yang tepat dan sederhana untuk mengajar.}

Cerita-cerita berupa perumpamaan dan perbandingan yang sangat mengesankan dipakaiNya utuk memikat perhatian para murid-murid. Cerita-cerita itu sering dipakai-Nya untuk menjawab pertanyaan dan para murid-murid-Nya diajak berpikir sendiri mengenai maksud dan arti cerita itu misalnya dalam Yohanes 15:1-7.Cerita yang mengesankan tak akan terlupakan, sehingga ajaran yang terdapat di dalamnya makin mendalam bagi murid-muridNya.

\section{Yesus Kristus menyatakan motif-motif yang kuat agar murid-murid-Nya menerima ajaran-Nya}

Tiap manusia cenderung menaruh perhatian besar pada kepentingan dirinya sendiri. Apa saja yang akan menolongnya untuk mencapai tujuannya, akan menarik perhatiannya. Yesus Kristus selalu menunjukkan hubungan antara ajaran yang diberikan-Nya dengan kebutuhan 
yang sedang digumuli oleh para murd-murid-Nya ,misalnya seperti yang tertulis dalam Yohanes 11:25-26.Persaingan atau harapan untuk memperoleh sesuatu yang berharga dalam dunia materi tak pernah dipakai-Nya sebagai motif untuk menerima ajaran-Nya.

\section{Yesus Kristus selalu mengaktifkan murid-muridnya-Nya.}

Yesus Kristus mengajak mereka bersoal-jawab.Ia mengajukan kepada mereka pertanyaanpertanyaan yang mendorong mereka untuk berpikir menemukan jawaban yang tepat. Ia memberikan kesempatan untuk berbuat sesuatu, murid-murid diajak memberi makan orang banyak (Yohanes 6:1-15). Mereka ditugaskan pergi meneruskan ajaran yang telah disampaikan-Nya kepada mereka (Yohanes 6:1-15).

\section{Yesus Kristus selalu memberikan kepada murid-murid-Nya tanggung jawab untuk mengambil keputusan secara pribadi (Yohanes 11:41,16:16-33 )}

Dengan jelas Ia menunjukkan akibat dari pilihan yang tepat dan yang tidak tepat. Tanggung jawab untuk memilih diserahkan sepenuhnya pada murid-murid-Nya. Ia tidak menyuruh mereka menghafalkan apa yang dikatakan-Nya dan taat secara mutlak tanpa berpikir. Sebaliknya, Ia mendorong mereka untuk berpikir sendiri dan mengambil keputusan dengan penuh kesadaran mengenai akibat pilihannya, yakin untuk mengikuti-Nya atau tidak. Ketaatan yang dipaksakan atau dilakukan tanpa berpikir bukanlah ketaatan sejati. Keputusan yang sah ialah keputusan yang diambil dengan penuh pengertian dan kerelaan.

Murid-murid Yesus Kristus yang pertama itu dipilih dari kalangan rakyat jelata. Mereka adalah orang-orang sederhana, buta huruf, para nelayan dari Galilea orang-orang yang tak bersekolah dalam ilmu dan adat kebiasaan para rabi, tetapi terlatih oleh disiplin kerja keras dalam mencari nafkah dan kesukaran. Mereka adalah orang-orang yang mempunyai kemampuan-kemampuan yang terbatas.Hidup mereka penuh dengan 
kekurangan dan persoalan dosa yang selalu menghantui mereka. Tidak jarang pula Yesus menyatakan bahwa Dia tetap mengasihi murid-murid-Nya sekalipun mereka kurang cepat menangkap ajaran Sang Guru.

Di sekolah seringkali tampak masalah perbedaan individu, misalnya ada murid yang lambat dan ada murid yang cepat belajarnya, ada yang cerdas, ada yang berbakat dalam bidang-bidang tertentu dan sebagainya.Peserta didik merupakan pribadi yang sedang bertumbuh dan berkembang. Apabila kita amati secara seksama, mungkin kita menghadapi dua peserta didik yang sama benar. Disamping memiliki kesamaan-kesamaan, tentu masingmasing anak memiliki sifat yang khas, yang hanya dimiliki oleh diri masingmasing.Timbulnya perbedaan ini dapat kita kembalikan kepada faktor pembawaan dan lingkungan sebagai komponen utama bagi terbentuknya keunikan individu.

Mengingat bahwa yang menjadi tujuan pendidikan adalah perkembangan murid yang optimal dari setiap individu, maka masalah perbedaan individu ini perlu mendapat perhatian dalam pelayanan pendidikan di sekolah. Dengan kata lain sekolah hendaknya memberikan pelayanan kepada murid-muridnya secara individu dengan keunikannya masing-masing. Masalah belajar yang terjadi dikalangan murid sering kali terjadi dan menghambat kelancaran proses belajar siswa. Dalam kegiatan belajar, sering timbul permasalan atau hambatan pada anak. Permasalahan belajar dapat timbul dari dalam diri anak sendiri (internal) maupun dari luar (eksternal). Hambatan internal meliputi fisiologis, biologis dan psikologis anak, mulai dari kecerdasan, motivasi, minat, sampai bakat si anak. Sedangkan hambatan eksternal meliputi linkungan social maupun lingkungan non-sosial.Untuk mencapai hasil belajar yang maksimal, hambatan belajar tersebut harus diatasi. Dengan rasa percaya diri yang dimiliki siswa, yang terbangun dari hubungan yang baik dengan sisiwa 
yang dilakukan guru, individu siswa akan sangat dengan mudah berinteraksi didalam lingkungan belajarnya. Rasa percaya diri adalah sikap percaya dan yakin akan kemampuan yang dimiliki, yang dapat membantu seseorang untuk memandang dirinya dengan positif dan realitis sehingga ia mampu bersosialisasi secara baik dengan orang lain. Seseorang yang selalu beranggapan bahwa dirinya tidak mempunyai kemampuan, merasa dirinya tidak berharga, merupakan gambaran diri orang yang mempunyai rasa percaya diri rendah. Oleh karena itu guru harus memiliki pengalaman nyata untuk melibatkan diri dalam hubungan yang baik terhadap siswa dengan mempraktikkan nilai-nilai dari pendidikan multikultural dalam kehidupan sehari-hari. Guru harus mengakui bahwa guru adalah perantaraperantara,yang dalam waktu dan cara Allah sendiri dipakai Allah untuk berbicara dalam hati dan kehidupan anak-anak ${ }^{6}$.Sehingga sikap dan perilaku yang toleran, simpatik, dan empatik pun pada gilirannya akan tumbuh pada diri masing-masing siswa. Dengan demikian, proses pembelajaran yang difasilitasi guru tidak sekadar berorientasi pada ranah kognitif, melainkan pada ranah afektif dan psikomotorik sekaligus. Pendekatan demokratis yang dilakukan guru dalam hubungan dengan siswa menempatkan guru dan siswa memiliki status yang setara,karena masing-masing dari mereka merupakan anggota komunitas kelas yang setara juga. Setiap anggota memiliki hak dan kewajiban yang absolut. Perilaku guru dan siswa harus diarahkan oleh kepentingan individu dan kelompok secara seimbang. Aturanaturan dalam kelas harus dibagi untuk melindungi hak-hak guru dan siswa sehingga terjadi hubungan yang baik dan seimbang.Guru sebagai kunci strategis dalam kelas maupun sekolah harus memiliki kompetensi social yang baik sehingga hubungan anak didik dengan

\footnotetext{
${ }^{6}$ Iris V Culluy ,Dinamika Pendidikan Kristen (Jakarta;Gunung Mulia,2011),hal.101
} 
guru akan mengundang nara didik yang selalu terbuka kepada guru dalam segala hal dan situasi proses belajar mengajar terjadi dengan efektif dan berkualitas.

\section{DAFTAR PUSTAKA}

Cully Iris V,Dinamika Pendidikan Kristen,Jakarta;BPK Gunung Mulia,2011

Kasan Tholib,Dasar-Dasar Pendidikan,Jakarta;Studia Press,2009

Tung Khoe Yao,Filsafat Pendidikan Kristen,Yogyakarta;Penerbit ANDI,2013

Price.J.M,Yesus Guru Agung,Bandung;Lembaga Literatur Baptis,2011

Sadirman A.M,Interaksi dan motivasi belajarmengajar,Jakarta;PT.Raja Grafindo

Persada,2009 